\title{
Assessment of a solar plant solution interconnected to national grid system in Paraguay
}

\author{
Frankz Lindstrom ${ }^{1,3 *}$, Gustavo Riveros ${ }^{1,3}$, Massimo Rivarolo ${ }^{2}$, Gustavo Arevalos ${ }^{3}$ \\ ${ }^{1}$ Parque Tecnológico Itaipu, Hernandarias, Paraguay \\ ${ }^{2}$ Thermochemical Power Group, University of Genoa, Via Montallegro 1, 16145 Genoa, Italy \\ ${ }^{3}$ Facultad de Ciencias y Tecnologías, Universidad Privada del Este, Pdte. Franco, Paraguay
}

\begin{abstract}
Paraguay has abundant hydroelectric energy (around 99\%, in 2017 a generation reached $96,387 \mathrm{GWh}$ ) and it is currently exporting part of this energy. Some studies carried out by the National Electricity Administration indicate an increase in the demand for electric power where it is observed that the Reserve Generation Margin would be affected by the year 2025. To face this scenario, Paraguay is investigating alternative sources to diversify its energy production mix: this paper focuses on solar plants. Within the Electric System Master Plan, Paraguay aims to expand and improve the electric power supply system, mainly in the western part of the country in the central region of the Paraguayan Chaco. In this context and based on the experience of the Itaipu Technology Park in the installation and operation of the first two solar plants in the country, already in operation in the mentioned region, the aim of this paper is the evaluation of a future photovoltaic solar plant in the area of Loma Plata, which will be connected to the national interconnected grid system, with a power around of $10 \mathrm{MWp}$. For this purpose, a thermoeconomic analysis with a software tool is used to evaluate the viability of the proposal, evaluate different configurations and select the best option for the case study.
\end{abstract}

\section{Introduction}

Paraguay is a small country in South America, with an estimated population around 7 millions of inhabitants [1] and a surface of $406,752 \mathrm{~km}^{2}$ [2]. The National Electricity Administration (ANDE) is in charge of the electric system in the whole country. The mission of this institution is to satisfy the needs of electricity in the country and act in the regional electricity sector, with social and environmental responsibility and excellence in administration and service, to contribute to the development of Paraguay and the welfare of its population [3]. Hydro energy is the main national energy resource. According to National Energy Balance [4] approximately 73 percent of the generated energy is exported,

* Corresponding author: frankz.lindstrom@gmail.com 
43,634 GWh in 2017, with neighboring Argentina and Brazil receiving the majority. In the same year, the electric power available for the national market was 15,577 GWh.

Although the country is one of the largest producers of electricity in the world, there are some places where the electricity grid does not arrive: this is the case of the Paraguayan Chaco or Western Region, consisting of more than $60 \%$ of Paraguay's land area, but with less than $10 \%$ of the population.

The generation sources connected to the National Interconnected System are: Itaipu Binational, Yacyreta Binational and Acaray hydroelectric power plants. The 2016-2025 ANDE master plan shows an average annual growth of $8.9 \%$ of the electrical energy demand in Paraguay; based on this data, it is expected that generation plants will have these characteristics of production in 2025 [5]:

- Acaray Hydroelectric Plant: dispatch of 214 MW (100\%).

- Yacyretá Binacional Hydroelectric Plant: dispatch of 1,336 MW (90\%).

- Itaipú Binacional Hydroelectric Plant: 5,172 MW dispatch (85\%).

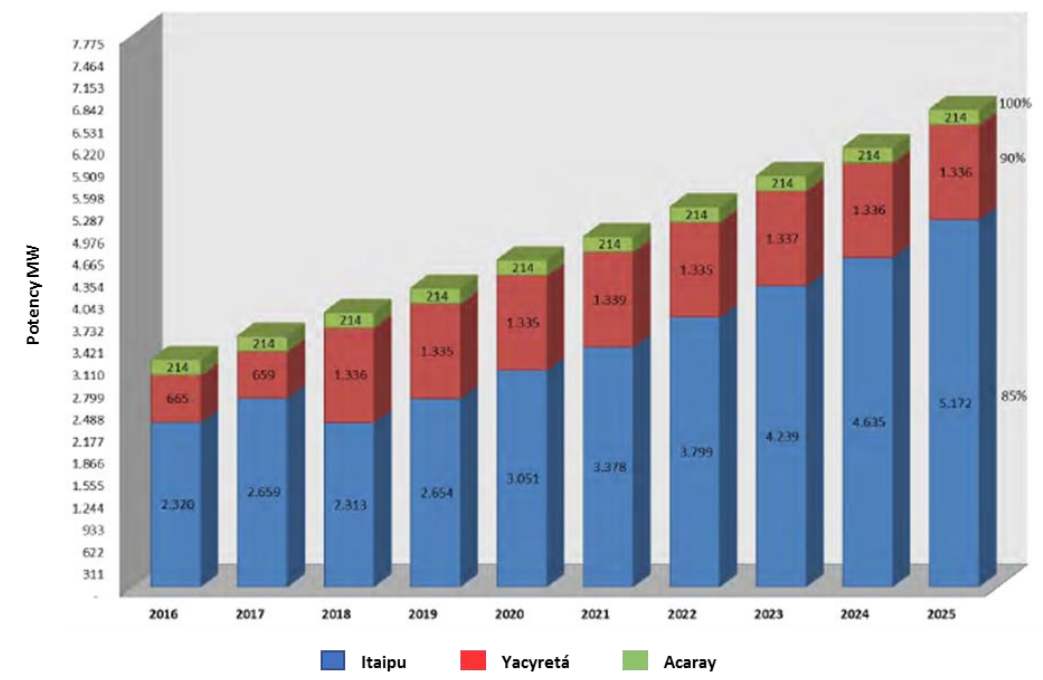

Fig. 1. Dispatch projected by the Master Plan of ANDE [5].

As shown in Figure 1, projection for 2025, the power generation available for the National Interconnected System is $7,775 \mathrm{MW}$ where $86 \%$ will be used to cover the projected electricity demand and $15.68 \%$ as Generation Reserve Margin, which is lower than the Planning Reserve Margin ${ }^{\dagger}$. According to the National Renewable Energy Laboratory (NREL), Paraguay has a great solar energy potential, with an estimative of $1,112,221,024 \mathrm{MWh}$ per year [5], indicating that the central and northeastern areas of the Western region of Paraguay are better for the installation of PV plants.

Currently, in the country there are two PV plants, located in the towns of Joel Estigarribia and Pablo Lagerenza, which are operational since 2014 and 2017, respectively. The data related to these plants, which were managed by the Itaipu Binacional and the Itaipu Technological Park (PTI), are used to carry out the case study.

\section{Case study}

\footnotetext{
${ }^{\dagger}$ The recommended value for reserve margin is $20 \%$ of the available electric power.
} 
In order to promote the development of the Western region of Paraguay (Paraguayan Chaco) and increase the Generation Reserve Margin, the Master Plan of ANDE includes the improvement of the National Interconnected System and the construction of a $10 \mathrm{MWp}$ PV Plant in the area of Loma Plata. This power plant will be connected to the $220 \mathrm{kV}$ future transmission network which will be available around 2025 [5]. This work addressed specifically the assessment of this proposed PV plant. Loma Plata is a town located in Boqueron Department, around $470 \mathrm{~km}$ from the capital Asuncion. The location can be observed in the map of Figure 2, where the future National Interconnected System and the above mentioned two PV plants are also represented. This town is recognized as an agrolivestock pole of Paraguay where several industries were installed [6], but the electrical infrastructure is one of the limiting factors for further development of the region. According to 2012 census, the entire department has 13,051 homes compared to the central department with 326,763 homes [7].

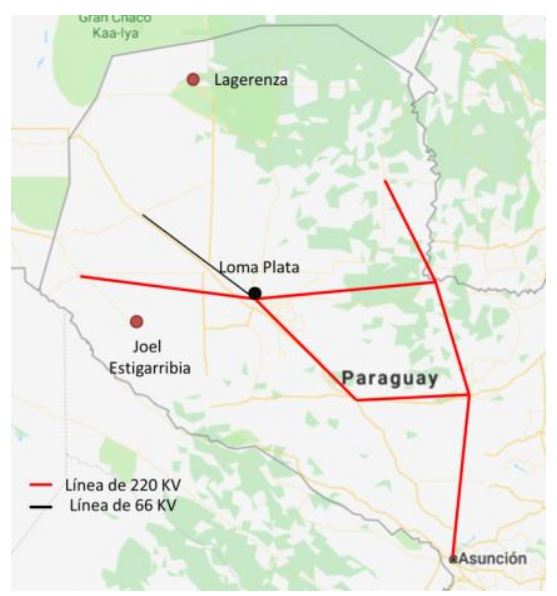

Fig. 2. Future Interconnected System and location of two PV plants.

\section{Energy and economic analysis}

Table 1 shows the estimated budget for a 10 MWp PV Plant, based on the installed cost of the power plant located in Lagerenza*, that was constructed along 2016 and the data are specifically for Paraguay. These costs were updated to 2018.

Table 1. Economic assumptions for Lagerenza PV plant

\begin{tabular}{|c|c|}
\hline Installed Potency & 10 MWp. \\
\hline Description & Estimated budget (Usd) \\
\hline Total Equipment: & $14,854,237$ \\
\hline - Photovoltaic Panels & $7,593,220$ \\
\hline - Inverter & $7,261,017$ \\
\hline Total Logistics & $1,694,915$ \\
\hline - Equipment & 338,983 \\
\hline - Materials & 677,966 \\
\hline - Assembly equipment & 677,966 \\
\hline
\end{tabular}

\footnotetext{
* It is a town located approximately $250 \mathrm{~km}$ from the case study.
} 


\begin{tabular}{|c|c|}
\hline Installed Potency & 10 MWp. \\
\hline Description & Estimated budget (Usd) \\
\hline Total Infrastructure & $29,470,003$ \\
\hline - Land & $2,690,342$ \\
\hline - Structure and assembly & $16,949,153$ \\
\hline - Auxiliary services & $3,389,831$ \\
\hline - Assembly services & $6,440,678$ \\
\hline TOTAL INVERSION & $46,019,156$ \\
\hline
\end{tabular}

In this estimation, a factor of economy of scale was not considered. It is worth noting that the most important voice of cost is due to infrastructure (29.47 MUSD), related to the remote area where the plant is going to be transported and installed. Furthermore, most of the infrastructure do not exist and must be specifically developed, leading to very high investment costs.

In order to have an estimation of the producibility of solar plants in Chaco Region, where the new plant is going to be installed, the available data from Joel Estigarribia (JE) plant have been considered, because it takes more time in operation. The plant has an installed capacity of $40 \mathrm{kWp}$, consisting in 160 panels ( $250 \mathrm{~W}$ each one), with a global area of $233 \mathrm{~m}^{2}$ and an efficiency of $15 \%$. The lifetime is estimated in 25 years and the efficiency at the end of life is predicted to be around $80 \%$ of the initial performance.

Production data of JE plant are available for the last three operational years (May 2016 - August 2018): the monthly productions are reported in Figure 3 below. The prodcution is quite constant in the period July - March, with average values higher than 3000 $\mathrm{kWh} /$ month; in five months of the year, the production reached $4000 \mathrm{kWh}$; the lowest values are in May (lower than $2000 \mathrm{kWh}$ ).

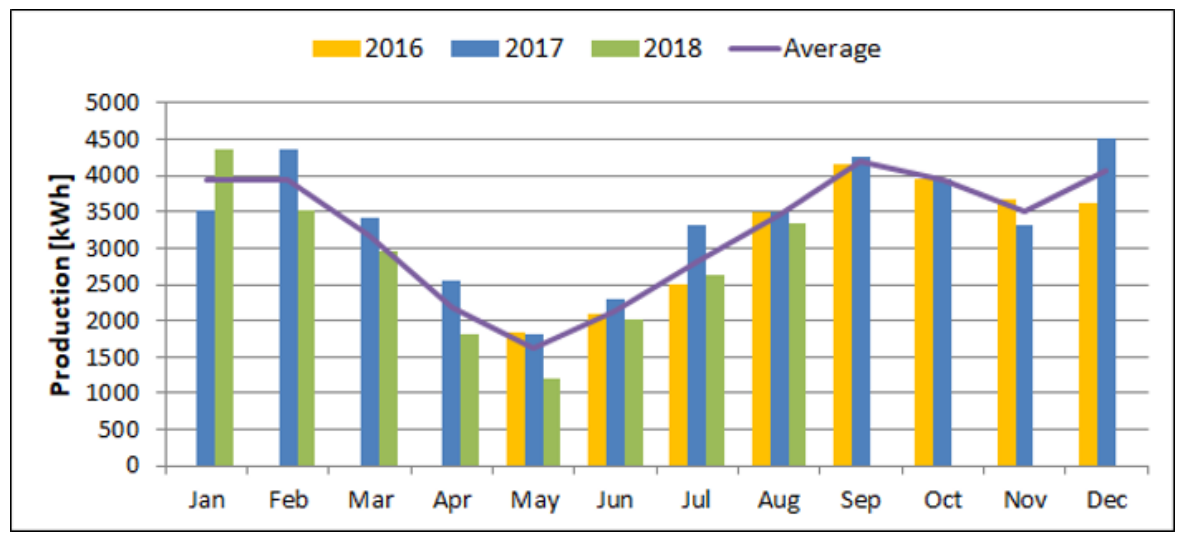

Fig. 3 : Production of Joel Estigarribia $40 \mathrm{kWp}$ solar plant.

Considering 2017 year as a case study, the total production was about 41 MWh: considering the plant capacity, it is easy to calculate the equivalent hours of the plant, defined as the ratio between annual production and installed power. In case of the JE plant, this value was about 1,020 hours. It can be insteresting to compare this value, with the avarage production of PV plants installed in Italy considering that Paraguay have no references for this comparison. Italy is one of the European Countries with the highest installed capacity (774,014 plants for an overall capacity of 19,682 MW at the end of 2017) and with favorable weather conditions for production $(22,104$ and $24,378 \mathrm{GWh}$ in 2016 and 2017 respectively) [8]. 


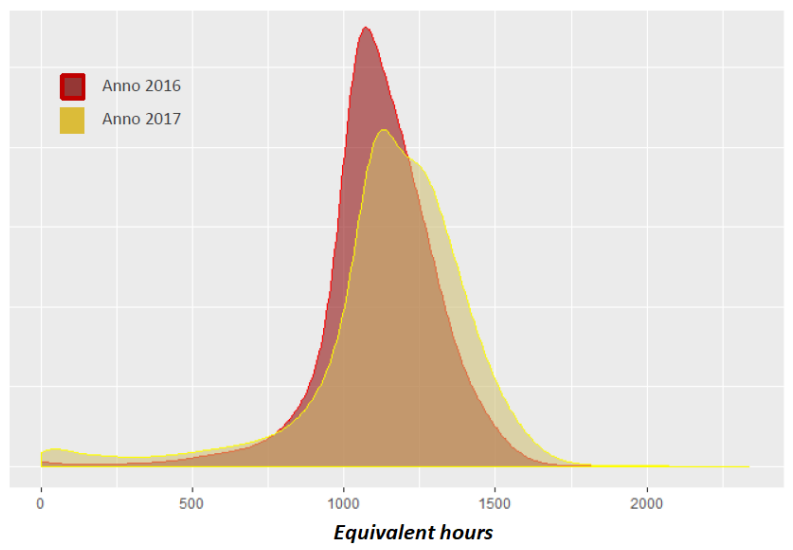

Fig. 4 : Equivalent production hours from PV plants in Italy (2016 and 2017) [8].

Assuming for the new $10 \mathrm{MWp}$ capacity PV plant a production trend similar to the one installed in JE, the producibility can be estimated in about 10,200 $\mathrm{MWh} /$ year. The aim of the economic preliminary analysis is to determinate the average energy production cost, employing the LCOE parameter. LCOE (Levelized Cost of Energy) is calculated throughout the whole plant lifetime, considering both fixed and variable annual costs, as reported in Eq. 1. In this case, variable costs are almost negligible (no fuel costs $C F$, operational and maintenance costs $C O$ are very low for this kind of plants), while investment annual costs $C I$ represent the most significative voice.

$$
L C O E=\frac{\sum_{j=0}^{M} C I_{j}(1+r)^{-i}+\sum_{i=0}^{N} C O_{i}(1+r)^{-i}+\sum_{i=0}^{N} C F_{i}(1+r)^{-i}}{\sum_{i=0}^{N}\left(E E_{i}\right)(1+r)^{-i}}
$$

Considering the investment cost reported in Tab. 1, the LCOE for this kind of plants can be estimated in about $160 € / \mathrm{MWh}$. Currently, Paraguay has no some energy policy for solar incentives and any economics studies regarding to the topic, therefore the authors have used the Italian experience as comparison point. The above mentioned value is alienated to the economic results officially reported for the Italian scenario, which is about $150 € / \mathrm{MWh}$ for plants installed at the ground with a capacity higher than $1 \mathrm{MW}$ [9]. For small size plants, typically installed on the roof, LCOE values are significantly higher (230 $€ / \mathrm{MWh}$ for $20 \mathrm{~kW}, 329 € / \mathrm{MWh}$ for $3 \mathrm{~kW}$, residential application) [9].

However, in Italy, as in the most of EU Countries, solar production was encouraged by the government, in particular in the first years, when costs were tipically higher. The first incentives forms started in 2006; new solar plants are no longer encouraged since 2013 in Italy. More in detail, Italy experimented five differents forms of incentives, named "Conto Energia", each one associated to a ministerial decree by the government. The $4^{\text {th }}$ Decree, in 2011 [iError! No se encuentra el origen de la referencia.] included different amounts of incentives, in $€ / \mathrm{kWh}$, according to the plant size, to the kind of installation (roof or ground) and to the energy utilization (self-consumption or injection to the electrical grid). In case of energy injection to grid, the Government provides a feed-in all inclusive tariff for electrical energy, fixed for each produced $\mathrm{kWh}$, as reported in Table 2. 
Table 2 : Economic incentives for PV plants in Italy [ ¿Error! No se encuentra el origen de la referencia.]

\begin{tabular}{|l|c|c|}
\hline Capacity $[\mathbf{k W}]$ & $\begin{array}{c}\text { Feed-in tariff for installation } \\
\text { on buildings }[\mathbf{\epsilon} / \mathbf{k W h}]\end{array}$ & $\begin{array}{c}\text { Feed-in tariff for other installations } \\
{[\boldsymbol{\epsilon} / \mathbf{k W h}]}\end{array}$ \\
\hline $1 \leq \mathrm{P} \leq 3$ & 0.375 & 0.346 \\
\hline $3<\mathrm{P} \leq 20$ & 0.352 & 0.329 \\
\hline $20<\mathrm{P} \leq 200$ & 0.299 & 0.276 \\
\hline $200<\mathrm{P} \leq 1000$ & 0.281 & 0.239 \\
\hline $1000<\mathrm{P} \leq 5000$ & 0.227 & 0.205 \\
\hline $\mathrm{P}>5000$ & 0.218 & 0.199 \\
\hline
\end{tabular}

Considering the installed capacity of the plant which is going to be installed in Loma Plata (10 MWp), the corresponding incentive would be $199 € / \mathrm{MWh}$, assuming the installation on the ground. The corresponding value would be about $20 \%$ higher than the LCOE, previously calculated. The Pay Back Period, defined as the time required for the cash inflows made from a project, to recover the initial investment, is a parameter which allows to evaluate if the investment can be considered safe:

$$
T C I=\sum_{j=1}^{P B P} \frac{C F N_{j}}{\left(1+r_{N P V}\right)^{j}}
$$

Lowest PBP values are given the highest preference. In this case, the PBP can be estimated in about 20 years, which would usually represents an high value, thus not a positive result. However, considering that, for these kind of plants, the annual incoming is constant (since the feed-in tariff is established by the government) and variable costs are almost zero, the PBP values is not affected by not controllable parameters (such as fuel costs). In conclusion, the above reported economic result can be considered acceptable. However, considering that in Paraguay the most of investment cost is related to the transportation and installation in a remote region, further encouragements may be provided, allowing for better economic results.

\section{Conclusions}

The present paper reports an economic feasibility analysis for the installation of PV plants in Paraguay in the remote region of Chaco, where fuel infrastructures are not available. The analysis of a $10 \mathrm{MWp}$ plant is considered, starting from the production of a $40 \mathrm{kWp}$ similar plant, installed in the same region. The availability of these plants are interesting, similar to PV plants installed in Italy, which is a leader Country in Europe (about $20 \mathrm{GW}$ installed). From the economic standpoint, costs are higher in Paraguay, due to installation costs in such a remote area: however, considering economic incentives, similar to the ones that were provided in Italy by the government in the last years, the economic results can be acceptable. Moreover, since the introduction of this technology can be of primary importance for Paraguay development, higher encouragment forms may be considered for installation in remote areas, leading to better economic results.

\section{References}

1. Dirección General de Estadísticas, Encuestas y Censo, Paraguay: Proyecciones de población nacional, áreas urbana y rural, por sexo y edad, Paraguay (2018)

2. Dirección del Servicio Geográfico Militar, Paraguay, (2019) 
3. Administración Nacional de Electricidad, Misión y Visión Institucional. Available at www.ande.gov.py, Paraguay (2019)

4. Vice-Ministerio de Minas y Energía, Balance Energético Nacional del Paraguay, Paraguay (2018)

5. Administración Nacional de Electricidad. Plan Maestro de Generación 2016-2025. Paraguay (2016)

6. Cámara de empresas maquiladoras del Paraguay. Loma Plata, epicentro del desarrollo chaqueño. Available at http://www.maquila.org.py/?p=2524, Paraguay (2019)

7. Dirección General de Estadística, Encuestas y Censos. Principales Indicadores de Viviendas 2012 Total País, Paraguay (2012)

8. A. Agrillo, M. dal Verme, P. Liberatore, D. Lipari, V. Maio, V. Surace, L. Benedetti, Rapporto statistic 2017: Energia da Fonti Rinnovabili ItaliaAnnual Report on Renewable Energy Sources, Italia (2018)

9. Ricerca Sul Sistema Energetico, Energia Elettrica, anatomia dei costi, 64 (2014)

10. Decreto 5, Incentivazione della produzione di energia elettrica da impianti solari fotovoltaici, Gazzetta Ufficialedella Repubblica Italiana, Serie generale 109, 103 (2011) 